E-ISSN: 2502-3101 P-ISSN: 2302-528x

http: //ojs.unud.ac.id/index.php/jmhu

\title{
Splitsing Perkara Pemutusan Hubungan Kerja Akibat Menolak Mutasi: Menguntungkan atau Merugikan Pekerja?
}

\section{Niki Anane Setyadani ${ }^{1}$, Holyness N. Singadimeja ${ }^{2}$}

${ }^{1}$ Fakultas Hukum Universitas Padjadjaran, E-mail: niki17001@mail.unpad.ac.id 2Fakultas HukumUniversitas Padjadjaran, E-mail:holyness@unpad.ac.id

\begin{tabular}{l}
\hline Info Artikel \\
\hline Masuk:23 Maret 2021 \\
Diterima:22 Juni 2021 \\
Terbit:31 Juli 2021 \\
Keywords: \\
Termination of Employment; \\
Mutation; Splitsing \\
\\
\\
Kata kunci: \\
Pemutusan Hubungan Kerja; \\
Mutasi; Splitsing \\
Corresponding Author: \\
Niki Anane Setyadani, E-mail: \\
niki17001@mail.unpad.ac.id \\
DOI: \\
10.24843/JMHU.2021.v10.i02.p10
\end{tabular}

Info Artikel

Keywords:

Termination of Employment; Mutation; Splitsing

Kata kunci:

Pemutusan Hubungan Kerja;

Corresponding Author:

Niki Anane Setyadani, E-mail:

DOI:

10.24843/JMHU.2021.v10.i02.p10

\begin{abstract}
The purpose of this paper is to examine the validity of termination of employment and transfer at PT. Indo Batam Ekatama and the accuracy of the legal basis used by judges to terminate employment relations. Furthermore, this paper also aims to examine the splitsing on labor law and the consequences of splitting in terms of the theory of justice and the theory of progressive law. The method used is a normative juridical method with a statutory approach and a conceptual approach. The results showed that the mutations and layoffs carried out by PT. Indo Batam Ekatama is illegitimate and workers are entitled to process wages but not entitled to religious holiday allowances. The legal basis used by the Panel of Judges in deciding cases is also deemed inappropriate. In addition, the concept of splitting lawsuit files on labor law has no legal basis and is considered contrary to a sense of justice because of the possibility of differences in judge decisions that result in differences in rights between workers who are dismissed.
\end{abstract}

\begin{tabular}{l}
\hline Abstrak \\
\hline Tujuan penulisan ini adalah untuk mengkaji keabsahan \\
pemutusan hubungan kerja dan mutasi pada PT. Indo \\
Batam Ekatama serta ketepatan dasar hukum yang \\
digunakan hakim untuk memutus hubungan kerja. \\
Selanjutnya, penulisan ini juga bertujuan untuk \\
mengkaji splitsing pada hukum ketanagakerjaan serta \\
konsekuensi dari dilakukannya splitsing ditinjau dari \\
teori keadilan dan teori hukum progresif. Adapun \\
metode yang digunakan adalah metode yuridis normatif \\
dengan pendekatan perundang-undangan dan \\
pendekatan konseptual. Hasil penelitian menunjukkan \\
bahwa mutasi dan PHK yang dilakukan PT. Indo Batam \\
Ekatama tidak sah dan pekerja berhak atas upah proses \\
namun tidak berhak atas Tunjangan Hari Raya \\
Keagamaan. Adapun dasar hukum yang digunakan \\
Majelis Hakim dalam memutus perkara juga dinilai \\
tidak tepat. Selain itu, konsep splitsing berkas gugatan \\
pada hukum ketenagakerjaan tidak memiliki dasar \\
hukum dan dinilai bertentangan dengan rasa keadilan
\end{tabular}


sebab adanya kemungkinan perbedaan putusan hakim yang mengakibatkan perbedaan hak antar para pekerja yang diPHK.

\section{Pendahuluan}

Kebutuhan akan lapangan pekerjaan semakin meningkat seiring dengan meningkatnya populasi penduduk Indonesia. Tidak seimbangnya pergerakan kurva kebutuhan pekerjaan dan lapangan pekerjaan menimbulkan beragam masalah sosial yang berakar dari pengangguran. Adapun pemenuhan hak dasar atas pekerjaan sejatinya telah dijamin oleh konstitusi melalui Pasal 27 ayat (2) Undang-Undang Dasar Negara Republik Indonesia 1945 yang mengamanatkan "Tiap-tiap warga negara berhak atas pekerjaan dan penghidupan yang layak bagi kemanusiaan." Konkretisasi dari penjelmaan amanat ini diwujudkan dengan kontinuitas pembangunan pada sektor ketenagakerjaan seperti di undangkannya Undang-Undang Nomor 13 Tahun 2003 tentang Ketenagakerjaan (UU Ketenagakerjaan).

Pembangunan sektor ketenagakerjaan harus senantiasa memperhatikan asas keterpaduan melalui koordinasi fungsional lintas sektoral pusat dan daerah. ${ }^{1}$ Sebagai aktor yang berperan penting dalam pembangunan nasional, tenaga kerja harus mendapat perlindungan baik berkaitan dengan hak maupun kesejahteraannya. Perlindungan ini ditengarai oleh hubungan yang tidak setara antara pekerja dan pengusaha atau disebut dengan hubungan subordinat. Hubungan tersebut dibuktikan dengan adanya unsur "perintah" pada hubungan kerja. Relasi antara pekerja dan pengusaha ini disebut dengan hubungan industrial. Artinya, hubungan keduanya akan terus menerus bergesekan sebab berbenturnya perbedaan kepentingan. Di sinilah pemerintah berperan untuk melindungi kedua stakeholder tersebut agar tercapainya keseimbangan. Meskipun beragam upaya telah dilakukan pemerintah, namun pada praktiknya pemenuhan perlindungan hak pekerja banyak menemui permasalahan.

Perselisihan hubungan industrial terbagi menjadi perselisihan mengenai hak, kepentingan, Pemutusan Hubungan Kerja yang selanjutnya disebut PHK, dan perselisihan antar serikat pekerja/serikat buruh hanya dalam satu perusahaan. PHK berarti pengakhiran hubungan kerja yang menimbulkan akibat selesainya hak dan kewajiban antara pengusaha dan pekerja. Tentu PHK merupakan hal yang sangat dihindari pekerja sebab mata pencaharian pekerja akan hilang, belum lagi ditambah beban keluarga dan lainnya. Sehingga PHK merupakan jalan terakhir bagi pengusaha dengan diwajibkannya berbagai upaya sebelum memutuskan memPHK pekerjanya.

Penyebab dari PHK bermacam-macam, salah satunya adalah menolak mutasi. UU Ketenagakerjaan menyebutkan bahwa ketika seorang pekerja mangkir atau tidak bekerja selama 5 hari berturut-turut dan telah dipanggil secara patut dan tertulis sebanyak dua kali namun pekerja tetap tidak hadir, maka pekerja akan dianggap mengundurkan diri. Ketidakhadiran ini biasanya disebabkan oleh pekerja yang tidak mau dimutasi atau menganggap mutasi yang dilakukan tidak sesuai dengan peraturan perundang-undangan yang berlaku.

${ }^{1}$ Maulida Indriani, “Peran Tenaga Kerja Indonesia Dalam Pembangunan Ekonomi Nasional," Gema Keadilan3, no. 1 (2016): 74-85. 
Sengketa hubungan industrial terkait mutasi yang berujung pada PHK salah satunya terjadi pada PT. Indo Batam Ekatama. Sebuah perusahaan yang bergerak di bidang press logam memutuskan hubungan kerjanya terhadap 14 pekerja dengan kualifikasi mengundurkan diri sebab pekerja dianggap tidak hadir di perusahaan tujuan mutasi selama 5 hari berturut-turut.

Upaya hukum yang ditempuh oleh pekerja dengan argumentasi bahwa mutasi yang dilakukan tidak sah ialah melayangkan gugatan ke Pengadilan Hubungan Industrial pada Pengadilan Negeri Bandung sebab PT. Indo Batam Ekatama berwilayah hukum di Bekasi yang masih merupakan kompetensi absolut dari Pengadilan Negeri Bandung. Gugatan ini dilakukan karena tidak tercapainya kesepakatan setelah dilakukannya proses mediasi oleh Mediator Dinas Tenaga Kerja Pemerintah Kabupaten Bekasi dengan dikeluarkannya Surat Anjuran Nomor: 565/1744/Disnaker tertanggal 08 Mei 2019 dan Risalah Penyelesaian Perselisihan Hubungan Industrial tertanggal 20 Mei 2019.

Dengan argumentasi dibutuhkannya saksi dari pihak pekerja yang diPHK untuk menguatkan dalil pekerja, surat gugatan yang dilayangkan oleh kuasa hukum Penggugat dari pihak pekerja dibagi menjadi dua perkara (splitsing). Splitsing dilakukan dengan masing-masing 7 pekerja sebagai penggugat. Permasalahan muncul setelah keluarnya putusan hakim yang menunjukkan adanya perbedaan baik dari pertimbangan hukum sampai pada pengenaan pasal klasifikasi PHK kepada pekerja sekaligus hak yang diterima pekerja.

Baik dalam Hukum Acara Perdata maupun Undang-Undang Nomor 02 Tahun 2004 tentang Penyelesaian Perselisihan Hubungan Industrial tidaklah ditemukan ketentuan mengenai splitsing. Perbedaan putusan akibat splitsing dengan tidak adanya perbedaan kondisi pekerja menimbulkan rasa ketidakadilan antar para pekerja sebab pekerja tidak mendapatkan hak yang sama. Hal ini tidaklah sesuai dengan pendapat Gustav Radbruch yang tertuang dalam bukunya berjudul "einführung in die rechtswissenschaften", yang menjelaskan tiga nilai utama dalam hukum, yaitu: keadilan (Gerechtigkeit), kemanfaatan (Zweckmassigkeit), dan kepastian hukum (Rechtssicherheit).

Selain mendasarkan pada teori keadilan, kajian mengenai splitsing perkara dengan putusan hakim yang berbeda ini juga dapat didasarkan pada ajaran Teori Hukum Progresif oleh Satjipto Rahardjo, hukum adalah untuk rakyat dan bukan sebaliknya. Hukum ada untuk harga diri manusia, kebahagiaan, kesejahteraan dan kemuliaan manusia. ${ }^{2}$ Dua komponen basis dalam hukum yakni peraturan dan perilaku. ${ }^{3}$ Hakim tidak lagi sebagai corong undang-undang melainkan menggunakan juga nuraninya. Dengan demikian, pelaku hukum termasuk hakim dituntut untuk memiliki empati terhadap rakyat yang tercermin dalam putusannya. Oleh karenanya, menarik untuk dikaji mengenai splitsing pada perkara PHK karena mutasi dikaitkan dengan teori hukum keadilan dan teori hukum progresif serta peraturan perundang-undangan yang berlaku.

Sejak dibuatnya tulisan ini, penulis belum menemukan artikel ilmiah yang membahas spesifik mengenai splitsing. Namun penelitian terkait PHK akibat menolak mutasi sendiri dapat ditemukan dan telah dilakukan beberapa kali oleh para penulis. Pertama, penelitian yang dilakukan pada tahun 2016 oleh Asri Luvitawati, mahasiswa Fakultas

2 Satjipto Rahardjo, Membedah Hukum Progresif (Penerbit Buku Kompas, 2006).h. 188.

${ }^{3}$ Ibid. 
Hukum Universitas Padjadjaran dengan judul "Analisis Putusan Pengadilan Hubungan Industrial Bandung No. 200/Pdt.Sus-Phi/2014/Pn/Bdg tentang Sengketa Perselisihan Hak Mengenai Mutasi dan Demosi Terhadap Serikat Pekerja Ditinjau dari Undang-Undang No. 13 Tahun 2003 Tentang Ketenagakerjaan". Tulisan tersebut mengkaji mutasi dan demosi yang tidak sesuai dengan Perjanjian Kerja Bersama yang telah disetujui PT. Diamond Cold Storage dan pekerjanya. Kemudian tulisan kedua ditulis oleh Jon Parulian Purba, mahasiswa Fakultas Hukum Universitas Padjadjaran dengan judul "Analisis Terhadap Putusan Mahkamah Agung Nomor: 511K/Pdt.Sus/2012 tentang Pemutusan Hubungan Kerja Secara Sepihak oleh PT Drydock Word Pertama Dikaitkan dengan Undang-Undang Nomor 13 Tahun 2003 tentang Ketenagakerjaan" pada tahun 2017. Fokus dari tulisan tersebut ialah perihal analisis mengenai pemutusan hubungan kerja sepihak dengan alasan perusahaan tidak memiliki proyek sedangkan kenyataannya perusahaan masih menjalankan empat proyek.

Kedua tulisan di atas membahas mengenai mutasi dan juga PHK oleh perusahaan yang kemudian menimbulkan sengketa. Namun lagi-lagi ditegaskan bahwa dari dua tulisan tersebut belum ada yang membahas mengenai perbedaan putusan hakim at as perkara yang displitsing pada kasus PHK karena mutasi.

Penelitian ini bertujuan untuk menganalisis dua pokok persoalan yakni mengenai keabsahan mutasi dan PHK oleh PT. Indo Batam Ekatama serta dasar hukum Majelis Hakim dalam memutus hubungan kerja. Selain itu penulisan juga bertujuan menganalisis mengenai perbedaan putusan hakim akibat splitsing serta pembahasan mengenai keabsahan splitsing pada hukum ketenagakerjaan. Oleh karenanya, tulisan ini akan dibagi menjadi dua bahasan. Pertama akan menjawab keabsahan mutasi dan PHK yang dilakukan oleh PT. Indo Batam Ekatama serta menganalisis dasar hukum Majelis Hakim dalam memutus hubungan kerja. Kedua, menganalisis perbedaan putusan hakim akibat splitsing serta kajian mengenai splitsing pada hukum ketenagakerjaan itu sendiri ditinjau dari teori keadilan dan teori hukum progresif.

\section{Metode Penelitian}

Adapun metode yang digunakan dalam penelitian ini ialah dengan menggunakan penelitian hukum normatif. Metode ini digunakan dengan tujuan melihat adanya kekosongan norma dalam splitsing pada perkara ketenagakerjaan juga penerapan hukum yang tepat pada PHK yang terjadi di PT. Indo Batam Ekatama. Pendekatan dalam metode penelitian ini yakni pendekatan the statute approach atau perundangundangan dan conseptual approach atau pendekatan konseptual. ${ }^{4}$ Bahan hukum yang digunakan dalam penelitian ini yakni UUD NRI 1945 dan peraturan perundangundangan yang berlaku. Adapun teknik pengumpulan bahan hukum menggunakan studi kepustakaan dengan menggunakan analisis kualitatif.

\footnotetext{
${ }^{4}$ Johnny Ibrahim, "Teori Dan Metodologi Penelitian Hukum Normatif," Malang: Bayumedia Publishing 57 (2006). h. 306.
} 


\section{Hasil dan Pembahasan}

\subsection{Pemutusan Hubungan Kerja Sepihak Akibat Menolak Mutasi oleh PT. Indo Batam Ekatama ditinjau dari Undang-Undang Nomor 13 Tahun 2013 tentang Ketenagakerjaan}

Perselisihan terjadi disebabkan pekerja atau buruh menolak untuk dimutasi dan kemudian diPHK dengan alasan mangkir kerja. Setidaknya terdapat dua komponen pertama yang patut dikaji yakni mengenai apakah mutasi dan PHK yang dilakukan PT. Indo Batam Ekatama telah sesuai dengan peraturan perundang-undangan yang berlaku atau tidak. Ketentuan mengenai mutasi diatur dengan delapan pasal dalam Bab IV Penempatan Tenaga Kerja pada UU Ketenagakerjaan bahwa penempatan tenaga kerja dilaksanakan berdasarkan asas terbuka, obyektif, serta adil, dan setara tanpa diskriminasi. Dapat diartikan bahwa mutasi dilakukan dengan memberikan informasi baik secara tertulis maupun lisan kepada para pekerja secara terbuka perihal jenis pekerjaan yang akan dilakukan di perusahaan baru, berikut upah beserta jam kerjanya. Selain itu, mutasi juga harus dilakukan dengan objektif dalam artian harus sesuai dengan kemampuan pekerja.

Ketentuan objektif ini selaras dan ditegaskan dengan Pasal 32 ayat (2) UU Ketenagakerjaan yang pada pokoknya menyatakan bahwa perusahaan harus menempatkan tenaga kerja pada jabatan yang tepat sesuai dengan keahlian, keterampilan, bakat, minat, dan kemampuan dengan memperhatikan harkat, martabat, hak asasi, dan perlindungan hukum. Selain diatur dalam Undang-Undang, ketentuan mutasi juga dapat diatur dalam perjanjian kerja secara tertulis sebagaimana tertuang dalam Pasal 54 huruf c dan d UU Ketenegakerjaan. Ketentuan ini sama halnya bagi perusahaan yang mencantumkan ketentuan mutasi di dalam peraturan perusahaan.

Pada dasarnya, asas kebebasan berkontrak dalam Pasal 1338 KUHPerdata memperbolehkan pengusaha dan pekerja menyepakati perihal ketentuan mengenai mutasi di dalam perjanjian kerja. Namun kebebasan berkontrak ini tidaklah mutlak dan dibatasi oleh Pasal 1337 KUHPerdata yakni tidak boleh bertentangan dengan undang-undang, kesusilaan, dan ketertiban umum. Begitu pula dengan perusahaan yang memiliki pekerja paling sedikit 10 orang yang wajib membuat peraturan perusahaan. Ketentuan dalam peraturan perusahaan dapat mencantumkan mengenai mutasi namun tidak boleh bertentangan dengan undang-undang, kesusilaan, dan ketertiban umum. Hal ini dipertegas dengan Pasal 111 ayat (2) UU Ketenagakerjaan yang menyebutkan bahwa ketentuan dalam peraturan perusahaan tidak boleh bertentangan dengan ketentuan peraturan perundang-undangan yang berlaku.

Peraturan perusahaan tidak diperbolehkan bertentangan dengan UU Ketenagakerjaan sebab ketentuan mengenai materi peraturan perusahaan telah diatur dan diberikan standar oleh UU Ketenagakerjaan. Dengan melakukan penafsiran hukum a contrario, 5 Pasal 111 ayat (2) UU Ketenagakerjaan menunjukkan bahwa materi peraturan perusahaan harus sesuai dengan materi UU Ketenagakerjaan. Apabila materi dalam peraturan perusahaan mengatur kembali materi dari peraturan perundang-undangan maka peraturan perusahaan tersebut haruslah mengatur lebih baik atau minimal sama dengan ketentuan peraturan perundang-undangan sebagaimana tertuang dalam Pasal 2 ayat (5) Peraturan Menteri Tenaga Kerja Nomor 28 Tahun 2014 tentang Tata Cara

\footnotetext{
5 Tommy Hendra Purwaka, "Penafsiran, Penalaran, Dan Argumentasi Hukum Yang Rasional," Masalah-Masalah Hukum 40, no. 2 (2011): 117-22.
} 
Pembuatan dan Pengesahan Peraturan Perusahaan Serta Pembuatan dan Pendaftaran Perjanjian Kerja Bersama.

Dalam perkara a quo, ketentuan mutasi diatur dalam Pasal 6 Peraturan Perusahaan PT. Indo Batam Ekatama berbunyi, "Mutasi adalah perpindahan pekerja dalam satu lokasi perusahaan maupun berbeda lokasi perusahaan dan atau pemindahan pekerja antara perusahaan dalam satu grup." Jika dikaitkan dengan materi mutasi dalam UU Ketenagakerjaan, maka dapat disimpulkan bahwa mutasi pada PT. Indo Batam Ekatama diperbolehkan berbeda lokasi perusahaannya dan atau berbeda perusahaan dalam satu grup sepanjang pekerja ditempatkan sesuai dengan keahlian, keterampilan, bakat, minat, dan kemampuannya.

Adapun nama-nama perusahaan satu grup sebagai tujuan mutasi tidak dirincikan dalam peraturan perusahaan sehingga tidak dapat diketahui apakah perusahaan tersebut sejenis dan sesuai dengan keahlian pekerja atau tidak. Peraturan perusahaan ini kemudian menimbulkan multitafsir yakni apabila perusahaan dalam satu grup yang dimaksud memiliki jenis pekerjaan yang sama, maka tentu telah sesuai dengan UU Ketenagakerjaan. Namun apabila perusahaan dalam satu grup ini berbeda jenis pekerjaannya dan tidak sesuai dengan keahlian pekerja, maka tentu bertentangan dengan UU Ketenagakerjaan sehingga mutasi dinilai tidak sah.

Dalam persidangan, diperoleh fakta dari bukti yang diajukan Penggugat bahwa pekerja dimutasi ke PT. Pertambangan Bumi Indonesia di Kendari yang bergerak di bidang pertambangan yang nyata-nyata berbeda jenis pekerjaannya dengan PT. Indo Batam Ekatama yang bergerak di bidang press logam. Jika hanya sebatas menelaah apakah mutasi yang dilakukan sesuai dengan peraturan perusahaan, maka jawabannya ialah sesuai, sebab peraturan perusahaan membolehkan mutasi dalam satu grup perusahaan. Namun akar permasalahannya ada pada peraturan perusahaan itu sendiri apakah bertentangan dengan materi muatan UU Ketenagakerjaan atau tidak.

Dengan melihat bahwa perusahaan memutasi pekerja ke perusahaan yang jenis pekerjaannya berbeda dan tidak sesuai dengan keahlian pekerja, maka dapat disimpulkan bahwa peraturan perusahaan pada PT. Indo Batam Ekatama tidak sesuai dengan UU Ketenagakerjaan. Konsekuensinya, maka mutasi yang dilakukan tidak sah dan bertentangan dengan undang-undang.

Selain memperhatikan ketentuan UU Ketenagakerjaan, perusahaan juga perlu memperhatikan peraturan lain yang mengatur mengenai mutasi apabila hendak memutasi pekerjanya. Salah satunya adalah Peraturan Daerah Kabupaten Bekasi (Perda Kabupaten). Pasal 47 Perda Kabupaten menyebutkan apabila sebuah perusahaan melakukan mutasi atau perpindahan pekerja keluar daerah, maka pihak perusahaan harus memberitahukan kepada perangkat Daerah mengenai mutasi tersebut dalam bentuk laporan 30 (tiga puluh) hari sebelum dilakukannya mutasi tersebut.

Pada persidangan ditemukan fakta bahwa PT. Indo Batam Ekatama tidak memberitahukan kepada Perangkat Daerah tentang mutasi yang dilakukan kepada 14 pekerja dengan alasan Perda Kabupaten masih dilakukan uji materil sehingga tidak dapat menjadi acuan dalam perkara ini. Namun penulis menemukan fakta bahwa pada saat perkara ini digugat ke pengadilan, uji materil di Mahkamah Agung masih berlangsung dan telah diputus dengan Putusan Mahkamah Agung Nomor 83 
P/HUM/2019 yang menyatakan tidak dapat diterimanya uji materil Perda Kabupaten. Sehingga dapat disimpulkan bahwa mutasi PT. Indo Batam Ekatama tidak sesuai dengan Perda Kabupaten.

Dasar hukum perusahaan memPHK pekerja dengan dasar hukum Pasal 168 ayat (1) UU Ketenagakerjaan yang pada pokoknya menyebutkan bahwa pekerja yang mangkir kerja 5 hari atau lebih berturut-turut dan telah dipanggil oleh pengusaha 2 kali secara patut dan tertulis dapat diputus hubungan kerjanya karena kualifikasi mengundurkan diri. Meskipun telah dilakukan pemanggilan secara patut dan tertulis sebanyak 3 kali, namun perlu diperhatikan bahwa pemanggilan tersebut dilakukan oleh PT. Indo Batam Ekatama, bukan perusahaan tujuan mutasi. Sedangkan seharusnya pemanggilan dilakukan oleh perusahaan tujuan mutasi.

Persoalan yang menjadi pokok kajian dalam penulisan ini adalah apakah ketidakhadiran pekerja ke lokasi mutasi merupakan kesalahan pekerja yang oleh karenanya pekerja berhak untuk diPHK dengan kualifikasi mengundurkan diri, sedangkan di sisi lain surat mutasi yang telah dibahas di awal batal demi hukum sebab bertentangan dengan UU Ketenagakerjaan dan Perda Kabupaten.

Menjawab persoalan tersebut, maka dapat ditinjau dari Pasal 1320 ayat (4) KUHPerdata yang mensyaratkan sahnya perjanjian dengan suatu sebab yang halal. Sebab ini dimaksudkan bahwa suatu perjanjian tidak boleh bertentangan dengan undang-undang sehingga konsekuensinya apabila syarat objektif ini tidak terpenuhi adalah perjanjian batal demi hukum.

Peraturan perusahaan yang berisi ketentuan mutasi merupakan petunjuk teknis dari perjanjian kerja yang dibuat oleh pekerja/buruh dengan pengusaha. ${ }^{7}$ Sehingga apabila materi peraturan perusahaan tidak memenuhi syarat sah perjanjian maka risiko hukumnya menjadi tidak sah dan batal demi hukum. Dengan batalnya surat mutasi yang kemudian dianggap tidak pernah ada, maka linear dengan tidak adanya kewajiban bagi pekerja untuk datang ke lokasi mutasi. Dapat disimpulkan bahwa ketidakhadiran pekerja ke lokasi mutasi bukanlah sebuah kesalahan pekerja dan dengan batalnya mutasi maka pekerja dianggap masih berstatus sebagai pekerja di PT. Indo Batam Ekatama dan PHK tersebut tidaklah sah.

Meskipun demikian, berdasarkan Pasal 100 Undang-Undang PPHI, Majelis Hakim dalam mengambil keputusan harus mempertimbangkan hukum, perjanjian yang ada, kebiasaan, dan keadilan. Selain itu, Majelis Hakim juga harus memperhatikan asas kepastian hukum, keadilan, dan kemanfaatan bagipara pihak. ${ }^{8}$ Apabila hubungan kerja masih tetap dilangsungkan, maka dinilai tidak akan membawa manfaat kepada para pihak disebabkan perselisihan yang terjadi.

Dari penjelasan tersebut semakin menguatkan argumen bahwa sudah sepatutnya hubungan kerja antara pekerja dan perusahaan diputus oleh Majelis Hakim dalam persidangan. Namun yang selanjutnya akan dibahas dalam penulisan ini adalah

${ }^{6}$ Deden Muhammad Surya, "Pemutusan Hubungan Kerja Pada Pekerja/Buruh Dengan Dasar Menolak Mutasi Ditinjau Dari Perspektif Asas Kepastian Hukum Dan Asas Keadilan," Jurnal Wawasan Yuridika 2, no. 2 (2018): 169-86.

7 Lalu Husni, "Pengantar Hukum Ketenagakerjaan Indonesia, Edisi Revisi Ke-12," PT. Rajagrafindo Persada, Depok, 2014. h.79.

8 Nur Iftitah Isnantiana, "Legal Reasoning Hakim Dalam Pengambilan Putusan Perkara Di Pengadilan," Islamadina: Jurnal Pemikiran Islam 18, no. 2 (2017):41-56. 
ketepatan Majelis Hakim dengan menggolongkan PHK berdasarkan Pasal 164 ayat (1) Undang-Undang Ketenagakerjaan pada perkara pertama dan Pasal 164 ayat (3) Undang-Undang Ketenagakerjaan pada perkara kedua.

Pasal 164 ayat (1) Undang-Undang Ketenagakerjaan mengandung unsur perusahaan tutup, disebabkan kerugian yang dialami perusahaan, kerugian berlangsung selama 2 tahun secara terus menerus, atau keadaan memaksa. Fakta yang terjadi sampai perkara ini digugat ke pengadilan ialah perusahaan PT. Indo Batam Ekatama tidak tutup dan masih beroperasi. Sehingga Pasal tersebut tidak sesuai jika digunakan sebagai dasar PHK pada perkara ini. Adapun yang membedakan dengan Pasal 164 ayat (3) UndangUndang Ketenagakerjaan adalah dalam pasal ini menyebutkan bahwa perusahaan dapat memPHK pekerja apabila perusahaan melakukan efisiensi. Ketika perusahaan melakukan efisiensi maka perusahaan dapat memPHK pekerja dengan kompensasi yang lebih besar sesuai ketentuan peraturan perundang-undangan dibandingkan Pasal 164 ayat (1) Undang-Undang Ketenagakerjaan. Hal ini dapat ditinjau dari surat jawaban pengusaha yang menyebutkan bahwa mutasi dilakukan untuk menghindari biaya operasional yang cukup besar sebab persediaan bahan baku yang susah diperoleh. Secara garis besar, efisiensi dilakukan perusahaan dengan dilatarbelakangi oleh tujuan untuk mengurangi beban perusahaan supaya dapat tetap beroperasi. ${ }^{9}$

Jika membaca Pasal 164 Undang-Undang Ketenagakerjaan secara menyeluruh, maka sejatinya Pasal 164 ayat (3) bukan merupakan bagian yang terpisah seluruhnya dengan Pasal 164 ayat (1). Makna Pasal 164 ayat (3) Undang-Undang Ketenagakerjaan tidak diartikan bahwa perusahaan dapat memPHK ketika adanya efisiensi semata melainkan perusahaan melakukan efisiensi dengan menutup perusahaannya. Penutupan ini bisa diartikan ketika perusahaan merupakan holding company dengan menutup perusahaan anaknya. Intinya bahwa frasa "perusahaan tutup" juga menjadi bagian dalam Pasal 164 ayat (3) Undang-Undang Ketenagakerjaan.

Putusan Mahkamah Konstitusi Nomor 19/PUU-IX/2011 tentang Pemutusan Hubungan Kerja menerangkan bahwa frasa "perusahaan tutup" dalam Pasal 164 ayat (3) UU Ketenagakerjaan bertentangan dengan Undang-Undang Dasar Negara Republik Indonesia Tahun 1945 dan tidak berkekuatan hukum mengikat sepanjang tidak dimaknai "perusahaan tutup permanen atau perusahaan tutup tidak untuk sementara waktu". Oleh karenanya, PHK hanya sah untuk dilakukan apabila perusahaan tutup secara permanen dan sebelumnya perusahaan telah melakukan sejumlah langkah dalam rangka efisiensi. ${ }^{10}$

Dengan menimbang bahwa PT. Indo Batam Ekatama tidak tutup secara keseluruhan dan masih beroperasi sampai saat ini, maka penggunaan Pasal 164 ayat (3) UndangUndang Ketenagakerjaan tentu tidaklah tepat. Pertama, Pasal tersebut diperuntukkan bagi perusahaan yang tutup sedangkan PT. Indo Batam Ekatama masih beroperasi. Kedua, perkara mengenai penolakan mutasi sama sekali tidak termasuk ke dalam lingkup Pasal 164 ayat (3) Undang-Undang Ketenagakerjaan yang membahas mengenai efiensi dan penutupan perusahaan. Jika benar perusahaan melakukan

\footnotetext{
${ }^{9}$ Kurnaedi Kurnaedi, “Efisiensi Perusahaan Sebagai Alasan Pemutusan Hubungan Kerja Pasca Putusan Mahkamah Konstitusi Nomor 19/PUU-IX/2011" (UNIVERSITAS 17 AGUSTUS 1945, 2019).

${ }^{10}$ Ibid.
} 
efisiensi, maka seharusnya perusahaan tidak menggantikan posisi pekerja yang dimutasi dengan pekerja yang baru. ${ }^{11}$

Dari penjelasan di atas, dapat dilihat bahwa yang menjadi pokok persoalan adalah disharmonisasi yang menjadi pertimbangan Majelis Hakim dalam memutus hubungan kerja, tidak termasuk kedalam dasar PHK yang ada pada Undang-Undang Ketenagakerjaan. Oleh karenanya dalam perkara ini Majelis Hakim menggunakan Pasal 164 ayat (1) dan (3) Undang-Undang Ketenagakerjaan sebagai dasar PHK padahal pasal tersebut sama sekali tidak berkaitan dengan perkara ini. Dengan demikian, putusan Majelis Hakim tidaklah tepat dalam hal menggunakan Pasal 164 ayat (1) dan (3) Undang-Undang Ketenagakerjaan sebagai dasar diputusnya hubungan kerja.

Tidak adanya dasar hukum yang tepat untuk memutus hubungan kerja oleh Majelis Hakim dengan alasan disharmonisasi, menimbulkan suatu kekosongan hukum. Kekosongan hukum dalam hukum positif lebih tepat disebut sebagai kekosongan undang-undang atau peraturan perundang-undangan. Perlu adanya pasal dalam Undang-Undang Ketenagakerjaan yang mengatur mengenai disharmonisasi sebagai dasar diputusnya hubungan kerja oleh Majelis Hakim.

Dengan mempertimbangkan pekerja yang tentu tidak mau diPHK namun sebaliknya dengan perusahaan yang tidak menginginkan pekerja bekerja kembali, maka menjadi logis apabila kompensasi yang diberikan oleh sebab alasan PHK karena disharmonisasi ialah uang pesangon sebesar 2 kali ketentuan Pasal 156 ayat (2), uang penghargaan masa kerja sebesar 1 kali ketentuan Pasal 156 ayat (3), dan uang penggantian hak sesuai ketentuan Pasal 156 ay at (4).

Selain kompensasi yang telah disebutkan sebelumnya, pekerja berhak atas hak lain seperti upah proses. Upah proses lahir dari Pasal 155 ayat (2) UU Ketenagakerjaan yang menyebutkan bahwa selama putusan lembaga penyelesaian perselisihan hubungan industrial belum ditetapkan, pengusaha dan pekerja harus tetap melaksanakan pekerjaannya, dan kewajiban pengusaha adalah membayar upah. Untuk jangka waktunya sendiri adalah selama 6 (enam bulan). ${ }^{12}$ Adapun lebihnya waktu dalam proses pengadilan hubungan industrial sebagaimana dalam UndangUndang PPHI bukan lagi menjadi tanggung jawab para pihak. ${ }^{13}$ Dengan demikian, berdasarkan UMK Kabupaten Bekasi 2019 yang menentukan upah minimum sebesar Rp4.146.126.18 (Empat Juta Seratus Empat Puluh Enam Ribu Seratus Dua Puluh Enam Ribu Delapan Belas Rupiah), jika dikalikan dengan 6 bulan maka masing-masing pekerja berhak mendapatkan upah proses sebesar Rp29.022.883.00 (Dua Puluh Sembilan Juta Dua Puluh Dua Ribu Delapan Ratus Delapan Puluh Tiga Rupiah).

Adapun hak lain pekerja yang perlu dianalisis ialah hak atas Tunjangan Hari Raya (THR). Sebelum menentukan pekerja mendapat THR atau tidak, perlu diperhatikan kembali waktu pemutusan hubungan kerja oleh hakim yang akan digunakan sebagai dasar penentuan berhak atau tidaknya pekerja atas THR. Berdasarkan Pasal 7 ayat (1) Peraturan Menteri Ketenagakerjaan Nomor 6 Tahun 2016 tentang Tunjangan Hari

${ }^{11}$ Lihat Putusan Pengadilan Nomor 77/Pdt.Sus-PHI/2020/PN. Bdg, hlm. 7.

12 Putusan Mahkamah Konstitusi Nomor37/PUU-IX/2011 tentang Upah Proses

${ }^{13}$ Lihat Surat Edaran Mahkamah Agung Nomor 3 Tahun 2015 tentang Pemberlakuan Rumusan Hasil Rapat Pleno Mahkamah Agung Tahun 2015 sebagai Pedoman Pelaksanaan Tugas Bagi Pengadilan, hlm. 4, poin $\mathrm{f}$. 
Raya Keagamaan Bagi Pekerja/Buruh di Perusahaan, pekerja yang berhak atas THR adalah pekerja waktu tidak tertentu yang mengalami pemutusan hubungan kerja terhitung sejak 30 hari sebelum Hari Raya Keagamaan.

Mengingat bahwa agama seluruh pekerja yang diPHK adalah agama Islam, ${ }^{14}$ maka untuk menentukan pekerja berhak atau tidaknya perlu melihat tanggal hari raya lebaran tahun 2019 yang jatuh pada 03-04 Juni 2019. Pekerja diPHK oleh perusahaan tertanggal 26 Desember 2018 dan diputus oleh hakim pada 29 Januari 2020 pada perkara pertama dan 14 Oktober 2020 sehingga pekerja tidak berhak atas Tunjangan Hari Raya Keagamaan.

\subsection{Analisis Putusan Pengadilan yang Displitsing Ditinjau dari Undang-Undang Nomor 2 Tahun 2004 tentang Penyelesaian Perselisihan Hubungan Industrial}

Hukum acara yang berlaku pada Pengadilan Hubungan Industrial ialah Hukum Acara Perdata sebagaimana dituangkan dalam Pasal 57 Undang-Undang PPHI yang berbunyi: "Hukum acara yang berlaku pada Pengadilan Hubungan Industrial adalah Hukum Acara Perdata yang berlaku pada Pengadilan dalam lingkungan Peradilan Umum, kecuali yang diatur secara khusus dalam undang-undang ini."

Salah satu proses penting dalam beracara adalah perihal pembuktian. Subekti mengartikan pembuktian sebagai suatu upaya yang digunakan untuk meyakinkan hakim atas kebenaran dalil yang dikemukakan di depan hakim. Sedangkan Sudikno Mertokusumo memberikan pandangan lain bahwa pembuktian merupakan upaya untuk memberi dasar yang cukup kepada hakim guna memberi kepastian tentang kebenaran peristiwa hukum tersebut. ${ }^{15}$ Pembuktian menjadi penting sebab akan menjadi bahan bagi pertimbangan hakim untuk membuat kesimpulan atas kebenaran perkara yang sedang berlangsung.

Undang-Undang PPHI tidak mengatur secara detil alat bukti perkara, namun mengingat bahwa hukum acara perdata merupakan pedoman dari hukum acara pada pengadilan hubungan industrial, maka ketentuan mengenai alat bukti yang digunakan adalah Pasal 164 HIR, yaitu:

\subsubsection{Bukti surat; \\ 3.2.2. Bukti saksi; \\ 3.2.3. Persangkaan; \\ 3.2.4. Pengakuan; \\ 3.2.5. Sumpah.}

Dari Pasal di atas, dapat dilihat bahwa alat bukti utama pada hukum acara perdata merupakan alat bukti tertulis. Hal ini disebabkan alat bukti tertulis yakni bukti surat dibuat dengan tujuan untuk membuktikan keadaan atau kejadian yang telah terjadi atau perbuatan hukum yang seharusnya dilakukan seseorang di masa yang akan datang. ${ }^{16}$

${ }_{14}$ Lihat Putusan Pengadilan Nomor 222 Pdt. Sus-PHI/2019/PN.Bdg hlm. 1-2. dan Putusan Pengadilan Nomor 77/Pdt.Sus-PHI/2020/PN.Bdg hlm 1-2.

${ }^{15}$ R. Subekti, Hukum Pembuktian (Jakarta: Pradnya Paramita, 2011). h.1.

16 Rosdalina Bukido, "Kedudukan Alat Bukti Tulisan Terhadap Penyelesaian Perkara Di Pengadilan," Jurnal Ilmiah Al-Syir'ah 9, no. 1 (2016).h. 476. 
Pada perkara pertama, alat bukti yang diajukan oleh Penggugat berupa alat bukti surat sebanyak 33 surat (P-1 sampai P-33). Sedangkan pada perkara kedua, alat bukti yang diajukan berupa alat bukti surat sebanyak 32 surat (P-1 sampai P-32). Alat bukti surat yang dimaksud seperti fotokopi surat pengangkatan karyawan, slip gaji, surat panggilan kerja, surat pemberitahuan $\mathrm{PHK}$, surat rancangan rotasi, peraturan perusahaan PT. Indo Batam Ekatama, dan Peraturan Daerah Kabupaten Bekasi No. 4 Tahun 2016 terkait Dispensasi dan Mutasi.

Adapun saksi sendiri merupakan orang yang memberikan keterangan di muka sidang, yang harus memenuhi syarat-syarat dan kualifikasi yang telah ditetapkan, dan memberikan kesaksian mengenai suatu peristiwa atau keadaan yang ia lihat, dengar, dan ia alami sendiri, sebagai bukti terjadinya peristiwa atau keadaan tertentu. ${ }^{17}$ Dalam perkara PHK, yang dapat menjadi saksi pada persidangan tidak selalu pekerja yang diPHK. A pabila ada pekerja lain yang tidak diPHK, dapat pula menjadi saksi dalam persidangan jika ia memenuhi kualifikasi sebagai saksi.

Baik dalam perkara pertama maupun kedua, pihak dari Penggugat sama-sama mengajukan saksi bernama Raman. Saksi Raman sendiri merupakan pekerja yang juga di PHK pada PT. Indo Batam Ekatama namun ia tidaklah menjadi Penggugat pada perkara pertama dan kedua melainkan Penggugat pada perkara ketiga yakni Perkara Nomor 184/Pdt.Sus-PHI/2020/PN. Bdg.

Secara garis besar, PT. Indo Batam Ekatama memPHK sebanyak 17 pekerja yang kemudian gugatan kepada PT. Indo Batam Ekatama dipisah menjadi 4 perkara dengan rincian sebagai berikut:

3.2.1. Putusan Nomor 222/Pdt.Sus-PHI/2019/PN. Bdg dengan 7 Penggugat;

3.2.2. Putusan Nomor 77/Pdt.Sus-PHI/2020/PN.Bdg dengan 7 Penggugat;

3.2.3. Putusan Nomor 184/Pdt.Sus-PHI/2020/PN. Bdg dengan 2 Penggugat; dan

3.2.4. Putusan Nomor 185/Pdt.Sus-PHI/2020/PN.Bdg dengan 1 Penggugat.

Pada saat penelitian ini dilakukan, putusan yang telah memiliki kekuatan hukum tetap ialah perkara pertama dan kedua yakni Putusan Nomor 222/Pdt.SusPHI/2019/PN.Bdg dan Putusan Nomor 77/Pdt.Sus-PHI/2020 PN.Bdg. Kedua perkara tersebut menunjukkan adanya perbedaan dalam putusannya baik dalam pertimbangan hakim sampai pada amar putusan. Adapun perkara ketiga dan keempat masih dalam proses pemeriksaan di pengadilan.

Pemisahan perkara dalam perkara ini dilakukan oleh kuasa penggugat disebabkan oleh adanya kebutuhan saksi.18 Salah satu Penggugat pada perkara ketiga merupakan saksi perkara perkara pertama dan kedua namun splitsing perkara tersebut menimbulkan konsekuensi yakni perbedaan putusan hakim dari masing-masing perkara yang berimbas pada perbedaan hak yang diterima oleh pekerja. Perbedaan ini tentu menyebabkan adanya ketidakpastian hukum dan juga tidak sesuai dengan rasa keadilan bagi pekerja.

Ketentuan normatif mengenai splitsing tidaklah ditemukan dalam hukum acara perdata maupun dalam Undang-Undang PPHI. Pemisahan perkara sejatinya dikenal

17 Subekti, Hukum Pembuktian. h. 9.

${ }^{18}$ Hasil wawancara dengan Bapak Sutrisno, sebagai Kuasa Hukum Para Penggugat dari Kantor Hukum “Budi Lahmudi, S.H \& Partners” pada 06 Oktober 2020. 
dalam Pasal 142 Kitab Undang-Undang Hukum Pidana yang memberikan kewenangan kepada Penuntut Umum untuk melakukan "pemisahan berkas perkara" . Pemisahan ini dilakukan dalam keadaan apabila terdapat kekurangan alat bukti dan kesaksian yang menghambat proses penegakan hukum. Pada perkara penyertaan, terdakwa harus saling bersaksi pada masing-masing perkara untuk mendukung pembuktian delik penyertaan atau yang disebut dengan saksi mahkota. 19 Splitsing dalam hukum acara pidana ini digunakan untuk menghindari kekurangan alat bukti saksi.

Pada praktiknya dalam perkara ketenagakerjaan, meskipun tidak diatur dalam hukum acara perdata maupun Undang-Undang PPHI, splitsing juga ditemui dalam pengajuan gugatan. Namun hal yang harus diperhatikan adalah perbedaan kedudukan saksi dalam hukum acara pidana dan hukum acara perdata. Pasal 184 ayat (1) UndangUndang Nomor 8 Tahun 1981 tentang Kitab Undang-Undang Hukum Acara Pidana menempatkan keterangan saksi sebagai alat bukti pertama yang kemudian dilanjutkan dengan keterangan ahli, surat, petunjuk, dan keterangan terdakwa. Hal ini menunjukkan pentingnya keterangan saksi sebagai konsekuensi teori pembuktian pada hukum acara pidana yang menerapkan pencarian kebenaran materiil oleh hakim pidana. ${ }^{20}$ Bahwa hakim pidana harus selalu berupaya mencari dan menemukan kebenaran yang sesungguhnya atau kebenaran riil.

Lain halnya dengan hukum acara perdata yang mencari kebenaran formil (formeel waarheid) sehingga kedudukan saksi diletakkan setelah alat bukti surat. Tentunya sejalan dengan prinsip hakim dalam hukum acara perdata yang bersifat pasif dalam memutus perkara yang mana kewenangan hakim dalam memeriksa dan memutus perkara terbatas pada apa yang diajukan oleh penggugat dan tergugat. Alat bukti saksi menjadi diperlukan jika bukti surat kurang cukup sehingga saksi ini menjadi pihak yang membenarkan atau menguatkan dalil-dalil yang diajukan di muka persidangan. ${ }^{21}$

Dengan demikian, maka splitsing pada perkara ketenagakerjaan khususnya perselisihan PHK, menjadi dibenarkan apabila memenuhi dua kondisi. Pertama, apabila bukti surat dianggap kurang dan kedua tidak adanya saksi lain yang dapat bersaksi di persidangan selain pekerja yang diPHK. Dalam perkara a quo, sebagaimana disebutkan sebelumnya bahwa sudah diajukannya 32 dan 33 alat bukti surat yang dengan itu menunjukkan tidak adanya indikasi kurangnya alat bukti berupa surat. Selain itu masih adanya pihak pekerja yang lain yang mengetahui PHK tersebut dan bisa menjadi saksi di persidangan sehingga splitsing sebenarnya tidaklah diperlukan.

Selain tidak adanya urgensi dari diperlukannya splitsing, hal yang patut dikaji untuk mendukung argumentasi perlu dihindarinya splitsing adalah konsekuensi hukum dari splitsing itu sendiri. Timbulnya ketidakpastian hukum dan tercederainya rasa keadilan bagi para pekerja tentu menjadi tidak terhindarkan sebab Majelis Hakim yang memutus perkara berbeda sehingga memiliki pertimbangan hukumnya masingmasing.

Dalam memandang suatu permasalahan yang tidak memiliki dasar hukum dalam peraturan perundang-undangan seperti splitsing pada hukum acara perdata, perlu dipastikan bahwa perbuatan hukum tersebut senantiasa sesuai dengan asas hukum.

19 Suryono Sutarto, “Hukum Acara Pidana Jilid I. Semarang," Badan Penerbit: UNDIP, 1991.h. 53. ${ }^{20}$ L.J. Van Apeldoom, Pengantar Ilmu Hukum (Jakarta: Pradnya Paramita, 1978). h. 263.

${ }^{21}$ O S Eddy, "Hiariej, Teori Dan Hukum Pembuktian," Erlangga, Jakarta, 2012. h. 85. 
Asas hukum (rechtsbeginsel) merupakan pikiran dasar yang umum dan latar belakang dari peraturan yang konkret dan dapat ditemukan dengan mencari sifat-sifat umum dalam peraturan konkret. ${ }^{22}$

PHK yang terjadi pada 17 pekerja pada PT. Indo Batam Ekatama menyebabkan perusahaan digugat ke pengadilan. Seharusnya hak yang diterima pekerja dari putusan hakim adalah sama karena 17 pekerja tersebut diPHK dengan alasan yang sama dan dalam keadaan yang sama. Tidak ada perbedaan kondisi pada 17 pekerja sehingga tidak ada alasan pekerja mendapatkan hak yang berbeda. Namun dengan splitsing perkara, Majelis Hakim memiliki pertimbangan yang berbeda sehingga menyebabkan hak pekerja menjadi berbeda. Fakta ini tentu menyebabkan pekerja merasa tidak adil dan menimbulkan keirian antar pekerja.

Jika dikaitkan dengan perkara a quo, pemenuhan rasa keadilan ini seharusnya tercermin dari kesamaan hak yang diterima para pekerja. Namun faktanya, kedua putusan hakim berbeda baik dari dasar hukum yang digunakan pada perkara tersebut sekaligus hak yang diterima pekerja. Persamaan dalam kedua putusan hakim adalah batalnya mutasi oleh perusahaan dan tidak terpenuhinya kualifikasi pada Pasal 168 ayat (3) UU Ketenagakerjaan. Hal ini sesuai dengan analisis pada pembahasan pertama yang menyatakan mutasi oleh perusahaan tidak sesuai dengan Perda Kabupaten dan UU Ketenagakerjaan. Namun pada perkara pertama, Majelis Hakim sama sekali tidak memberikan pertimbangan terhadap kesesuaian mutasi dengan Perda Kabupaten.

Adapun pokok perbedaan putusan ada pada penggolongan PHK yang mana perkara pertama menyebutkan bahwa pekerja terbukti bersalah dengan menolak penugasan mutasi sehingga PHK digolongkan berdasarkan ketentuan Pasal 164 ayat (1) UU Ketenagakerjaan. Sedangkan Majelis Hakim pada perkara kedua mempertimbangkan bahwa dengan tidak sahnya mutasi maka tidak ada kesalahan pada pekerja sehingga pemutusan hubungan kerja oleh hakim diputus tanpa kesalahan pekerja.

Majelis Hakim pada perkara pertama kurang cermat dalam hal tidak mempertimbangkan materi mutasi Peraturan Perusahaan yang bertentangan dengan UU Ketenagakerjaan, serta tidak pula mempertimbangkan Perda Kabupaten sebagai dasar ketidakabsahan mutasi. Kemudian, adanya inkonsistensi Majelis Hakim dalam memutus adanya kesalahan pekerja akibat menolak mutasi padahal pertimbangan sebelumnya menyebutkan bahwa mutasi tidaklah sah. Selanjutnya, penerapan Pasal 164 ayat (1) UU Ketenagakerjaan kurang sesuai jika digunakan hakim untuk memutus PHK dengan kualifikasi menolak mutasi sebab Pasal tersebut tidaklah mengatur mengenai mutasi. Pasal tersebut mengatur PHK akibat perusahaan tutup sedangkan faktanya PT. Indo Batam Ekatama masih beroperasi. Terakhir, penerapan 93 ayat (1) UU Ketenagakerjaan untuk menjadi dasar tidak berhaknya pekerja atas THR juga dianggap kurang sesuai sebab Pasal tersebut sama sekali tidak berbicara mengenai THR. Seharusnya Majelis Hakim lebih memperhatikan peraturan perundangundangan lainnya yang berlaku dalam memberikan putusan.

Sedangkan pokok dari perkara kedua ialah bahwa mutasi batal demi hukum dan dinilai bertentangan dengan UU Ketenagakerjaan dan Perda Kabupaten namun tidak mempertimbangkan pihak yang memberikan surat panggilan mutasi. Kemudian waktu PHK yang ditetapkan Majelis Hakim kurang sesuai sebab dijatuhkan 6 bulan

${ }^{22}$ Sudikno Mertokusumo, "Mengenal Ilmu Hukum," Yogyakarta: Liberty, 1986. h. 32. 
sejak PHK perusahaan yang dianggap batal. Padahal dengan diputusnya perkara pada saat putusan dibacakan, pekerja tetap berhak mendapat upah proses. Adapun THR yang diberikan Majelis Hakim seharusnya tidak diperoleh pekerja sebab putusnya hubungan kerja oleh hakim tidak terhitung 30 hari sebelum Hari Raya Keagamaan. Terakhir penggunaan Pasal 164 ayat (3) UU Ketenagakerjaan telah tepat sebab PHK pekerja dilakukan tanpa adanya kesalahan merupakan keputusan yang logis dan sesuai dengan hak pekerja.

Menurut analisis penulis, pertimbangan hukum masing-masing Majelis Hakim tidak sepenuhnya sesuai dengan peraturan perundang-undangan. Perkara pertama lebih sesuai dalam memperhatikan pihak yang mengeluarkan surat panggilan kerja, namun secara materil perkara kedua lebih sesuai sebab memberikan analisis terhadap kesesuaian materi mutasi pada Peraturan Perusahaan dibandingkan dengan UU Ketenagakerjaan dan Perda Kabupaten.

Adapun pertimbangan penggolongan PHK yang berdampak pada hak yang diperoleh pekerja lebih tepat pada perkara kedua. Hal ini sebab Majelis Hakim konsisten dengan pernyataan sebelumnya bahwa mutasi batal demi hukum sehingga PHK pekerja bukanlah merupakan kesalahan pekerja. Sehingga pekerja berhak mendapat hak sebagaimana tertuang dalam Pasal 164 ayat (1) UU Ketenagakerjaan. Kurang cermatnya Majelis Hakim dalam memberikan pertimbangan hukum sampai pada putusan, tentu sangatlah disayangkan. Ajaran Hukum Progresif yang diusung dan digagas oleh Satjipto Rahardjo menekankan pada konsep bahwa hukum adalah untuk rakyat dan hukum harus selalu pada status "law in the making" atau hukum selalu berproses untuk menjadi. ${ }^{23}$

Konsep ajaran progresif lahir dari adanya ketidakpuasan terhadap status hukum a quo yang dinilai belum maksimal. Satjipto menekankan bahwa seharusnya hukum tidak hanya dimaknai sebagai undang-undang tertulis melainkan juga harus dibarengi dengan penegakan hukum yang baik serta menggunakan nurani dalam menegakkan hukum itu sendiri. Pada splitsing perkara a quo, di samping melakukan analisis dengan aturan normatif yang berlaku, juga harus diperhatikan konsekuensi hukum splitsing perkara. Selain justru menimbulkan ketidakadilan dan bertentangan dengan konsep tujuan hukum yang telah dibahas sebelumnya, splitsing perkara juga menimbulkan ketidakpercayaan masyarakat terhadap hakim sebagai penegak hukum. Padahal jika mendasarkan pada ajaran hukum progresif, penegak hukum seperti hakim berperan sangat penting dalam menentukan tercapai atau tidaknya tujuan hukum. Perbedaan putusan hakim lahir sebab hakim memiliki pertimbangan yang berbeda yang dapat dicegah dengan meniadakan splitsing perkara.

Konsep kedua yakni law in the making diartikan bahwa hukum selalu berproses. Dengan tidak adanya dasar hukum dan kejelasan hukum mengenai splitsing perkara, tentu pemangku kebijakan haruslah mempertimbangkan untuk membuat suatu regulasi yang tepat dan utuh mengenai splitsing. Munculnya rasa ketidakadilan bagi para pekerja terkait, tentu tidak sesuai dengan hukum progresif yang juga mendasarkan pada paham Legal Realism dan Freirechtslehre yang pada pokoknya

${ }^{23}$ Farkhani Farkhani, "Filsafat Hukum; Paradigman Modernisme Menuju Post Modernisme," 2018. h. 180. 
hukum progresif memiliki tipe responsif. ${ }^{24}$ Permasalahan dan konsekuensi hukum yang diakibatkan splitsing perkara sudah cukup untuk dijawab oleh hukum agar dapat dikatakan hukum responsif terhadap isu-isu yang ada.

\section{Kesimpulan}

PHK yang dilakukan PT. Indo Batam Ekatama dengan alasan pekerja menolak mutasi adalah batal demi hukum sebab materi mutasi pada Peraturan Perusahaan bertentangan dengan Undang-Undang Ketenagakerjaan dan Perda Kabupaten Bekasi. Selain itu, ketentuan perusahaan harus memanggil pekerja yang dimutasi secara patut dan tertulis juga tidak terpenuhi sebab pihak yang melakukan pemanggilan bukanlah perusahaan tujuan mutasi. Kemudian, dasar hukum Majelis Hakim di kedua perkara dalam memutus perkara tidaklah tepat sebab tidak ada keterkaitan antara PHK menolak mutasi dengan Pasal 164 Undang-Undang Ketenagakerjaan yang mensyaratkan tutupnya perusahaan. Pekerja juga berhak atas uang proses selama 6 bulan namun tidak berhak atas Tunjangan Hari Raya Keagamaan. Putusan pada dua perkara tidak sepenuhnya sesuai dengan Undang-Undang yang berlaku. Putusan perkara pertama tidak mempertimbangkan Perda Kabupaten sebagai dasar ketidakabsahan mutasi. Selain itu, adanya inkonsistensi Majelis Hakim dalam memutus PHK padahal menyatakan mutasi tersebut tidaklah sah. Pada perkara kedua, Majelis Hakim mengabaikan panggilan secara patut dan tertulis yang tidak dilakukan oleh perusahaan tujuan mutasi serta tidak tepatnya pemberian hak THR kepada pekerja. Adapun ketentuan mengenai pemisahan berkas gugatan atau splitsing tidak dikenal hukum acara perdata dan Undang-Undang PPHI. Selain tidak memiliki dasar hukum, praktek splitsing bertentangan dengan rasa keadilan dalam masyarakat. Hal ini disebabkan adanya kemungkinan perbedaan putusan hakim yang mengakibatkan perbedaan hak antar para pekerja yang di PHK.

\section{Ucapan terima Kasih (Acknowledgments)}

Ucapan terima kasih penulis tujukan untuk seluruh pihak yang terlibat dan berkontribusi dalam terselesaikannya penulisan ini. Terima kasih juga kepada teman-teman penulis dan pihak dari Udayana Master Law Journal yang telah memberikan kesempatan dalam penerbitan penelitian ini.

\section{Daftar Pustaka}

\section{Buku}

Apeldoorn, L.J. Van. Pengantar Ilmu Hukum. Jakarta: Pradnya Paramita, 1978.

Eddy, O S. “Hiariej, Teori Dan Hukum Pembuktian." Erlangga, Jakarta, 2012.

Husni, Lalu. "Pengantar Hukum Ketenagakerjaan Indonesia, Edisi Revisi Ke-12." PT. Rajagrafindo Persada, Depok, 2014.

Ibrahim, Johnny. "Teori Dan Metodologi Penelitian Hukum Normatif." Malang: Bayumedia Publishing 57 (2006).

Mertokusumo, Sudikno. “Mengenal Ilmu Hukum.” Yogyakarta: Liberty, 1986.

${ }^{24}$ Mulyana W Kusumah and Paul S Baut, Hukum, Politik Dan Perubahan Sosial (Yayasan Lembaga Bantuan Hukum Inodnesia, 1988). h. 11. 
Rahardjo, Satjipto. Membedah Hukum Progresif. Penerbit Buku Kompas, 2006.

Subekti, R. Hukum Pembuktian. Jakarta: Pradnya Paramita, 2011.

\section{Jurnal}

Bukido, Rosdalina. "Kedudukan Alat Bukti Tulisan Terhadap Penyelesaian Perkara Di Pengadilan." Jurnal Ilmiah Al-Syir'ah 9, no. 1 (2016).

Farkhani, Farkhani. "Filsafat Hukum; Paradigman Modernisme Menuju Post Modernisme," 2018.

Indriani, Maulida. "Peran Tenaga Kerja Indonesia Dalam Pembangunan Ekonomi Nasional." Gema Keadilan 3, no. 1 (2016): 74-85.

Isnantiana, Nur Iftitah. "Legal Reasoning Hakim Dalam Pengambilan Putusan Perkara Di Pengadilan." Islamadina: Jurnal Pemikiran Islam 18, no. 2 (2017): 41-56.

Kurnaedi, Kurnaedi. "Efisiensi Perusahaan Sebagai Alasan Pemutusan Hubungan Kerja Pasca Putusan Mahkamah Konstitusi Nomor 19/PUU-IX/2011." UNIVERSITAS 17 AGUSTUS 1945, 2019.

Kusumah, Mulyana W, and Paul S Baut. Hukum, Politik Dan Perubahan Sosial. Yayasan Lembaga Bantuan Hukum Inodnesia, 1988.

Purwaka, Tommy Hendra. "Penafsiran, Penalaran, Dan Argumentasi Hukum Yang Rasional." Masalah-Masalah Hukum 40, no. 2 (2011): 117-22.

Surya, Deden Muhammad. "Pemutusan Hubungan Kerja Pada Pekerja/Buruh Dengan Dasar Menolak Mutasi Ditinjau Dari Perspektif Asas Kepastian Hukum Dan Asas Keadilan." Jurnal Wawasan Yuridika 2, no. 2 (2018): 169-86.

Sutarto, Suryono. "Hukum Acara Pidana Jilid I. Semarang." Badan Penerbit: UNDIP, 1991.

\section{$\underline{\text { Tesis }}$}

Fauzia, R. Tinjauan Yuridis Pertimabangan Hakim dalam Perkara Perselisihan PHK: Studi Terhadap Putusan PHK Efisiensi", Universitas Muhammadiyah Surakarta, 2017.

\section{Peraturan Perundang-Undangan}

Faillissmentsverodening, Staatsblad 1905 Nomor 217 juncto Staatsblad 1906 Nomor 348 Kitab Undang-Undang Hukum Perdata, terjemahan Subekti an R. Tjitrosudibjo, Jakarta: Pradya Paramita, 1980.

Undang-Undang Dasar Negara Republik Indonesia Tahun 1945.

Undang-Undang Nomor 13 Tahun 2003 tentang Ketenagakerjaan.

Undang-Undang Nomor 2 Tahun 2004 tentang Penyelesaian Perselisihan Hubungan Industrial.

Undang-Undang Nomor 48 Tahun 2009 tentang Kekuasaan Kehakiman.

Peraturan Menteri Tenaga Kerja Nomor 6 Tahun 2016 tentang Tunjangan Hari Raya Keagamaan Bagi Pekerja/Buruh di Perusahaan.

Keputusan Menteri Tenaga Kerja Republik Indonesia No.150 Tahun 2000 tentang Penyelesaian Pemutusan Hubungan Kerja dan Penetapan Uang Pesangon, Uang Penghargaan Masa Kerja, dan Ganti Kerugian di Perusahaan.

Putusan Mahkamah Konstitusi (MK) Republik Indonesia Nomor 37/PUU-IX/2011 tentang Upah Proses.

Putusan Mahkamah Konstitusi Nomor 19/PUU-IX/2011 tentang Pemutusan Hubungan Kerja. 
Surat Edaran Mahkamah Agung Nomor 3 Tahun 2015 tentang Pemberlakuan Rumusan Hasil Rapat Pleno Mahkamah Agung Tahun 2015 sebagai Pedoman Pelaksanaan Tugas Bagi Pengadilan. 